\title{
Inventory Level Analysis of Horticultural Commodities Exported by PT BSL from Central Java Indonesia to Singapore
}

\author{
AM Sa'dun Nashih ${ }^{1}$, Kuncoro Harto Widodo ${ }^{*}, 1,2$, and Dyah Ismoyowati ${ }^{1}$ \\ ${ }^{1}$ Department of Agro-industrial Technology, Faculty of Agricultural Technology \\ Universitas Gadjah Mada, Jl. Flora No.1 Bulaksumur 55281, Indonesia. \\ ${ }^{2}$ Center for Transportation and Logistics Studies, Universitas Gadjah Mada \\ Email: kuncorohw@ugm.ac.id*
}

\begin{abstract}
Horticultural commodities, in Indonesia, are one of the main clusters of export commodities. The demand of the commodities is relatively high due to the high economic level of consumers in Singapore. The exporter, e.g., PT BSL, had difficulties to meet the demand of Singapore's importer. This problem will be analyzed with inventory system in the supply chain of vegetables and fruits exported from Central Java Indonesia to Singapore. To identify the problem, we combine a dynamic system approach and its validation. The data on existing conditions (with the level of rejection $=20 \%$ ) were then formulated and modeled with two alternative scenarios, scenario1 and 2. In scenario 1, the level of rejection was set at the level of $10 \%$, while scenario 2 at the level of $30 \%$. Based on the simulation results, it was found that the average level of inventory in the scenario 1 was at $661.9 \mathrm{~kg}$ per day, while in scenario 2 were $112.34 \mathrm{~kg}$ per day.
\end{abstract}

Keywords: dynamic systems, horticultural commodities, inventory, supply chain

\section{INTRODUCTION}

Horticultures are classified into vegetables, fruits, ornament plants and biopharmacy plants. During the trade, these fresh commodities, especially, requires appropriate handling because of its perishable property.

Within the context of export trade, we need to identify the commodities supply chain of the export process from the ultimate farmer to the ultimate consumer. Widodo et.al (2011) and Heizer and Render, (2010), stated that Supply Chain Management (SCM) is a management of commodities flow, information flow and inherent modal flow as well from the begining to the end of business chain in order to optimize the fulfil of need for all entities within the chain.

According to Widodo et al (2003), in case of fresh agricultural commodities, its supply chain should consider the following characteristics: 1) "plant flowering" and "plant growing" of each commodity, 2) the number of harvestable fresh products influenced by its "plant growing" which is difficult to control, 3) loss process of fresh products started just after harvested and depending on handling process, and 4) all of the harvested fresh commodities should be directly consumed by the consumer or used for raw material in food or beverage industries before getting pilferage.

In this paper, therefore, we use supply chain framework to describe and to analyze the problem but focus on inventory system process for exporting horticultural commodities from Central Java Province Indonesia to Singapore. Then, for illustrating the real condition of inventory and the dynamic of its supply chain system process, we use simulation model. Furthermore, in the final step we generate the scenario model to analyze the change of inventory level within supply chain.

\section{RESEARCH METHODOLOGY}

We provide a case study in PT BSL and its supply chain members which is located at Magelang district, Central Java Province. The primer data was collected from September to October 2013 by in depth interview method. After collected primer and secondary data then we proceed the following steps : formulate the interaction between the sub-systems and its dynamic relation, elaborate the need analysis 
for every entity, draw the causal loop diagram, simulate the existing model, validate the data by using Mean Absolute Percentage Error (MAPE) and generate the basic scenarios for understanding the inventory level performance.
After we simulate the existing model then the data both from the supply side and the demand side as well are validated using MAPE in Equation 1. By using Equation 1, we have 3 conditions as follows: if MAPE $<5 \%$, the model is very valid, if $5 \%<$ MAPE $<10 \%$,

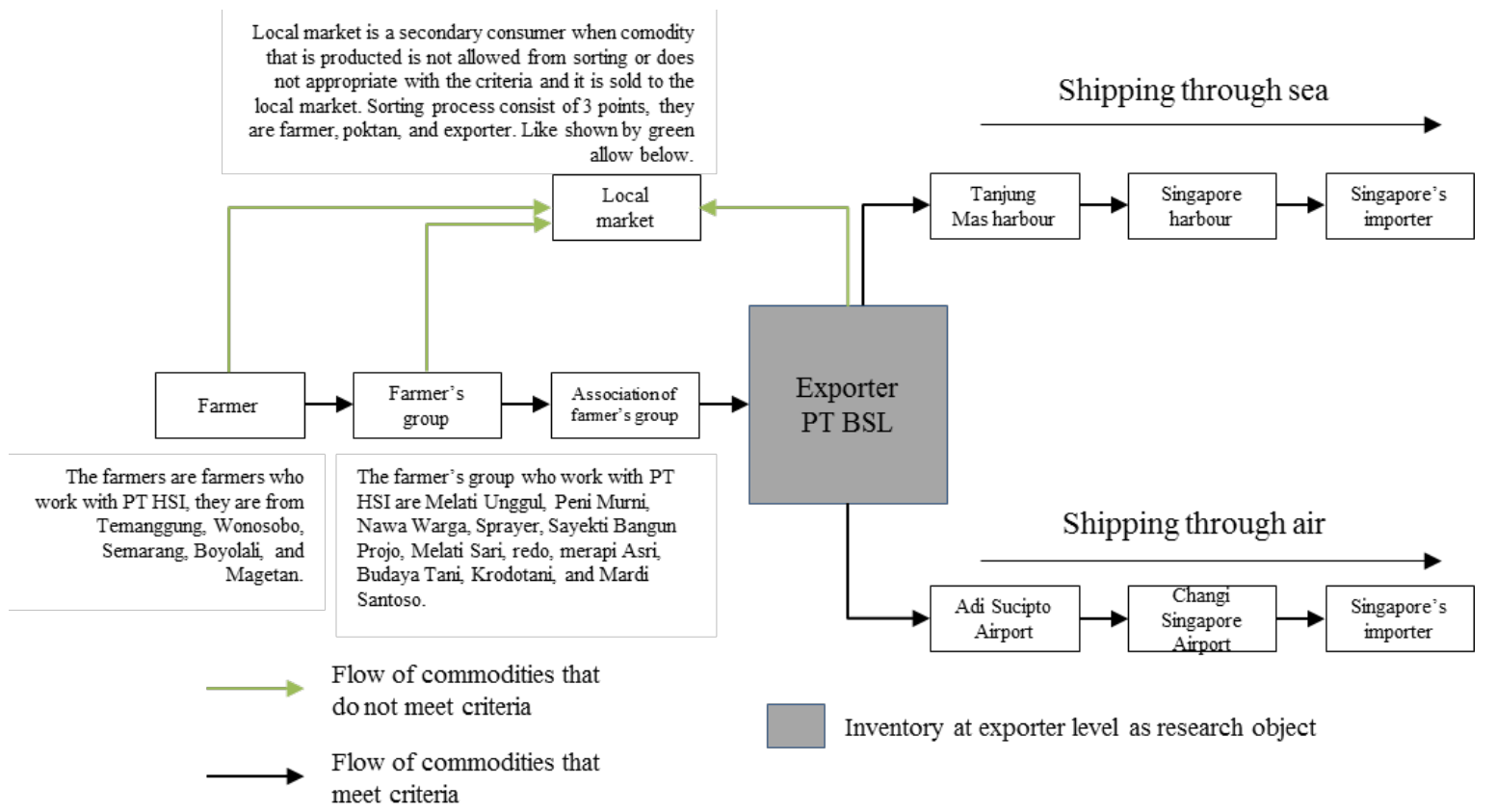

Figure 1 Supply Chain of commodities exported from Central Java Province Indonesia to Singapore (PT Sumber Sari lestari Fruit and Vegetables Exporter, 2014)

\section{RESULT AND DISCUSSION}

Based on the research methodology, we got the following results. Figure 1 shows the supply chain of horticultural commodities exported from Central Java Province Indonesia to Singapore. Figure 2 is the causal loop diagram of the supply chain, which explainsHowever, it focused more on the inventory system of the PT BSL.This causal loop diagram help us to model and simulate the existing condition as described in Figure 3. is valid, and otherwise is not valid. Tables 1 and 2 show the validation result.

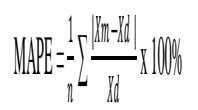

Table 3 provide information about inventory level during 3 years from 2013, 2014 and 2015 as well for existing condition, scenario 1 with rejection $10 \%$ and scenario 2

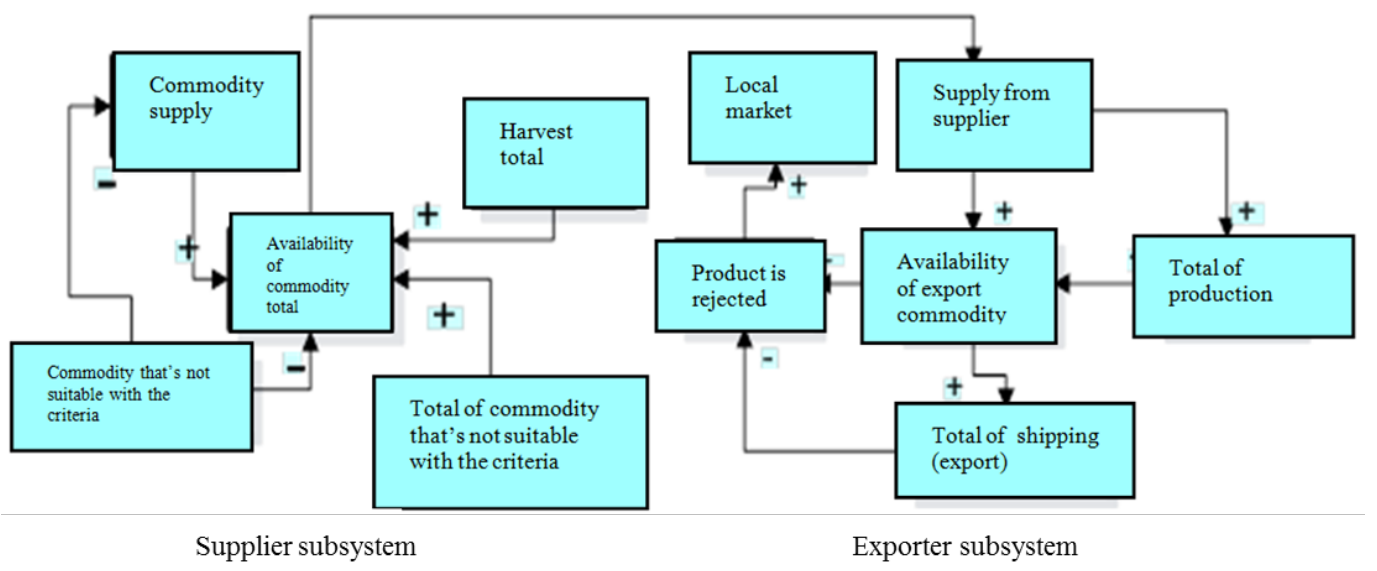

Figure 2 Causal loop diagram of inventory system 
with rejection $30 \%$. The red color cell show the zero level inventory and the yellow one represented the available inventory.

Table 1 Data validation for supply

\begin{tabular}{|l|c|c|}
\hline Commodities & MAPE (\%) & Validation \\
\hline Radish & 5.04 & valid \\
\hline Big green chili & 6.16 & valid \\
\hline Big red chili & 8.56 & valid \\
\hline Baby potato & 6.35 & valid \\
\hline Medium potato & 6.64 & valid \\
\hline Potato XL & 4.79 & valid \\
\hline Baby stringbean & 5.72 & valid \\
\hline Super stringbean & 6.12 & valid \\
\hline Melon & 7.02 & valid \\
\hline
\end{tabular}

In scenario 1, we obtain that there is no inventory on February, April, June, August and October Year 2013 and January, February, June, July, August and October Year 2014, and only August Year 2015 in which the average inventory is $661.9 \mathrm{~kg} /$ month. On the other hand, in scenario 2, there is no inventory on January, February, March, April, June, August, October and December Year 2013, and February, March, April, July, August and September Year 2014. However, in 2015 there is no inventory during 10 months, and inventory only available on March and October. The average inventory in scenario 2 is $112.34 \mathrm{~kg}$ per day. Therefore, the average of inventory level in scenario 1 is higher than in scenario 2.

Table 2 Data validation for importer's demand

\begin{tabular}{|l|c|c|}
\hline Commodities & MAPE (\%) & Validation \\
\hline \hline Radish & 5.04 & valid \\
\hline Big green chili & 6.16 & valid \\
\hline Big red chili & 8.56 & valid \\
\hline Baby potato & 6.35 & valid \\
\hline Medium potato & 6.64 & valid \\
\hline Potato XL & 4.79 & valid \\
\hline Baby stringbean & 5.72 & valid \\
\hline Super stringbean & 6.12 & valid \\
\hline Melon & 7.02 & valid \\
\hline
\end{tabular}

\section{CONCLUSIONS}

We obtained the following conclusions according to the result and discussion. First, the supply chain system was identified into three sub-systems: suppliers (farmer, farmer's group, and farmer's groups association), exporter and consumers (importer and local market). Second, in the existing condition a number of horticulture inventory, supplied/derived from various regions in Central Java Province Indonesia, were prepared to fulfill demand from Singapore's importers. Third, the data on existing conditions (with the level of rejection $=20 \%$ ) were then formulated and modeled with two alternative scenarios, scenario1 and 2. In scenario 1 , the level of rejection was set in the level $10 \%$ and scenario2 was in the level $30 \%$. Based on the simulation results, it showed that the level of inventory in the scenario 1 was at an average of $661.9 \mathrm{~kg}$ per day, and in scenario 2 was at an average of $112.34 \mathrm{~kg}$ per day inventory.

\section{REFERENCES}

Nashih, AMS., 2014. Analisis Tingkat Persediaan Ekspor Komoditas Hortikultura (Sayur dan Buah) PT Bumi Sari Lestari Fruit and Vegetables Exporter ke Singapura. Bachelor thesis. Universitas Gadjah Mada

Heizer,J. and Render, B, 2010. Operations management, 10th edition. Prentice Hall.

Widodo, K.H, Nagasawa, H., Morizawa, K and Ota, M., 2003. Basic Supply Chain for Agricultural Fresh Products. International Conference on Production Research, Virginia, USA.

Widodo, K.H., Arbita, K.P.D, and Abdullah, A. 2011. Supply Chain Management Agroindustri yang Berkelanjutan. Bandung : Lubuk Agung. 
Table 3 Inventory level for each scenario

\begin{tabular}{|c|c|c|c|c|c|c|c|c|c|}
\hline \multirow{4}{*}{ Month } & \multicolumn{9}{|c|}{ Simulation Result of Inventory Level } \\
\hline & \multicolumn{3}{|c|}{ existing with reject $20 \%$} & \multicolumn{3}{|c|}{ scenario 1 with reject $10 \%$} & \multicolumn{3}{|c|}{ scenario 2 with reject $30 \%$} \\
\hline & \multicolumn{3}{|c|}{ (kg/month) } & \multicolumn{3}{|c|}{ (kg/month) } & \multicolumn{3}{|c|}{ (kg/month) } \\
\hline & 2013 & 2014 & 2015 & 2013 & 2014 & 2015 & 2013 & 2014 & 2015 \\
\hline January & 1863.01 & 13403.86 & 6736.41 & 32365.28 & 0.00 & 19252.03 & 0.00 & 2285.92 & 0.00 \\
\hline February & 3988.25 & 0.00 & 3337.68 & 0.00 & 0.00 & 18567.14 & 0.00 & 0.00 & 0.00 \\
\hline March & 53803.09 & 21152.82 & 17504.53 & 44401.02 & 32114.80 & 31698.24 & 0.00 & 0.00 & 1475.06 \\
\hline April & 0.00 & 6550.33 & 7918.61 & 0.00 & 9156.70 & 15419.52 & 0.00 & 0.00 & 0.00 \\
\hline May & 0.00 & 10926.16 & 0.00 & 20376.26 & 16583.09 & 19818.21 & 14001.55 & 25782.65 & 0.00 \\
\hline June & 0.00 & 1732.32 & 0.00 & 0.00 & 0.00 & 22443.21 & 0.00 & 146.50 & 0.00 \\
\hline July & 18991.69 & 22892.98 & 0.00 & 15216.48 & 0.00 & 13610.53 & 6018.56 & 0.00 & 0.00 \\
\hline August & 0.00 & 12178.70 & 37872.27 & 0.00 & 0.00 & 0.00 & 0.00 & 0.00 & 0.00 \\
\hline September & 0.00 & 0.00 & 0.00 & 13476.89 & 25846.46 & 26952.81 & 18612.85 & 0.00 & 0.00 \\
\hline October & 0.00 & 0.00 & 16408.91 & 0.00 & 0.00 & 11051.04 & 0.00 & 9168.62 & 1670.15 \\
\hline November & 0.00 & 11838.34 & 0.00 & 17324.52 & 7044.54 & 38308.43 & 30550.98 & 11540.22 & 0.00 \\
\hline December & 15529.97 & 0.00 & 22139.92 & 0.00 & 2183.22 & 5678.05 & 0.00 & 82.49 & 0.00 \\
\hline
\end{tabular}

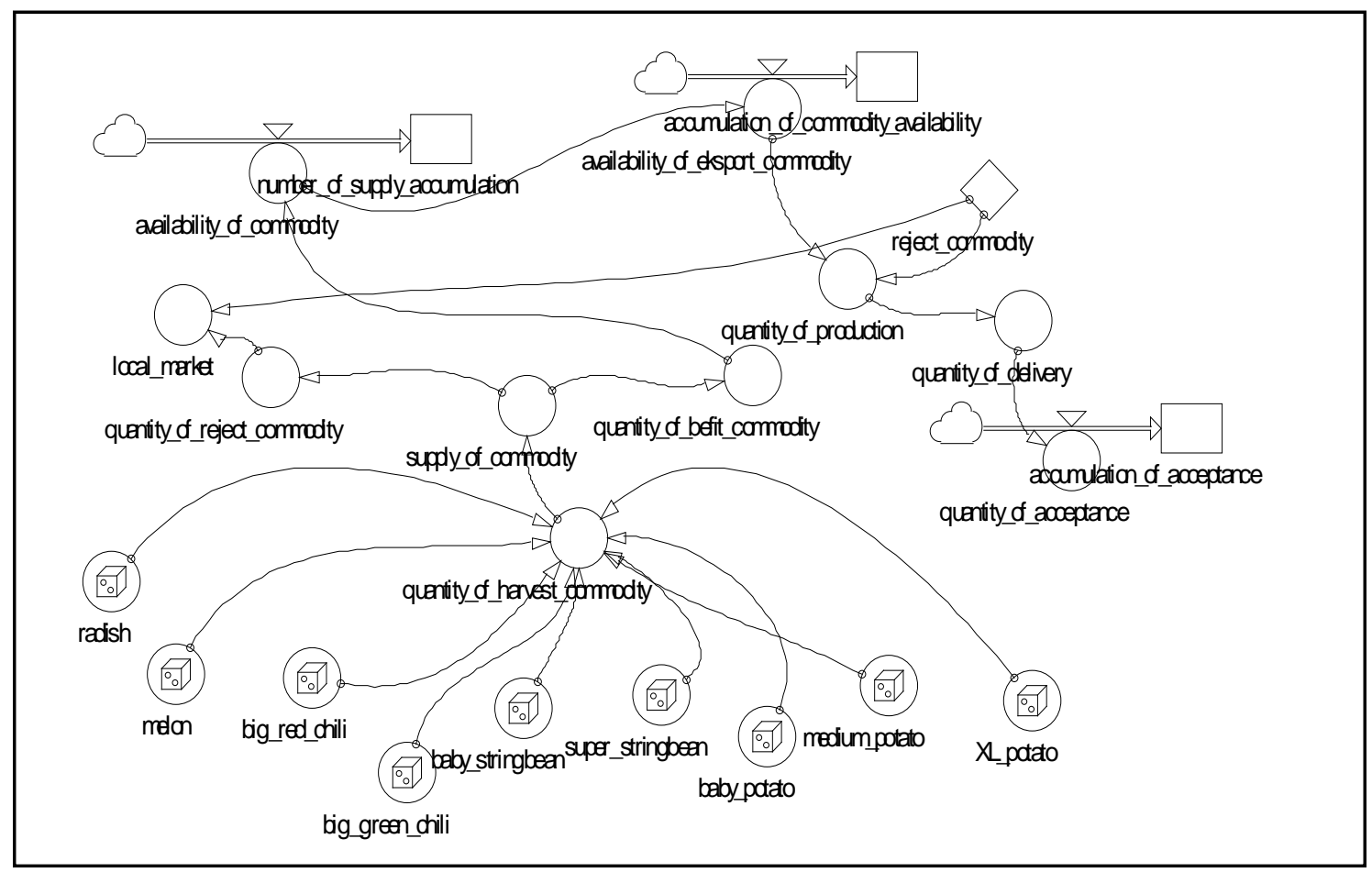

Figure 3 Simulation of the existing model 